\title{
Heavy Metal Induced Gene Expression in Plants
}

\author{
Abdul Razaque Memon (Corresponding author) \\ Faculty of Arts and Sciences, Usak University, \\ 1 Eylul Campus, 64200, Usak, Turkey \\ E-mail: armemon@usak.edu.tr \\ Nuriye Merakli \\ Faculty of Arts and Sciences, Usak University, \\ 1 Eylul Campus, 64200, Usak, Turkey \\ E-mail: nuriyemrkli004@ hotmail.com \\ Fatma Kusur \\ Faculty of Arts and Sciences, Usak University, \\ 1 Eylul Campus, 64200, Usak, Turkey \\ E-mail: fatmakusur@hotmail.com \\ Orcan Demircan \\ Faculty of Arts and Sciences, Usak University, \\ 1 Eylul Campus, 64200, Usak, Turkey \\ E-mail: orcan.demircan@usak.edu.tr \\ Emine Ayaz \\ Faculty of Arts and Sciences, Usak University, \\ 1 Eylul Campus, 64200, Usak, Turkey \\ E-mail: ayaz.emine05@ hotmail.com \\ Muhammet Memon \\ Izmir International Biomedicine and Genome Institute (IBG - Izmir) \\ Dokuz Eylül University Health Campus, \\ Balcova, 35340, Izmir, Turkey \\ Email: mfmdna@gmail.com
}

\begin{abstract}
Elements such as $\mathrm{Cd}, \mathrm{Zn}, \mathrm{Cu}, \mathrm{Cr}$ and $\mathrm{Pb}$ are known as heavy metals and can be released from many materials to the biosphere as a result of industrial and other human activities and can cause severe environmental pollution. High concentrations of these heavy metals in the soil have negative effects on the growth, development and crop yield. The remediation of these pollutants from the environment especially from the contaminated soil and water is an important task for environmentalists and agricultural scientists in order to make our precious soil and water resources clean and reusable for our agricultural industry and for safe human consumption. It is important to develope new and less expensive technologies to remediate contaminated areas and eliminate the potential deleterious effects of these contaminants which may pose serious problems to our food quality and health, if not addressed properly. Phytoremediation, an in situ remediation technique, could be one of the best approach through which toxic metals can be extracted from the polluted soils and waters and is considered as an environmentally sustainable and low-input approach for remediation of contaminated soils and waters. These techniques use the hyperaccumulator plants to remove toxic contaminants from the medium in situ (soil and/or water) and transport to the roots and accumulate them in their aerial parts which could be harvested and removed from the site. However, it is a relatively new technology and there are not many researches available in order to understand the molecular mechanism of uptake, transport and accumulation of the toxic metals/metalloids in the harvestable parts of the plants. Recent research has shown great advances in the understanding of key mechanisms that function in heavy metal detoxification, transport and accumulation in plants. For example; genes of metal transporters, metal ATPases, microRNAs involved in translocation and accumulation process have been identified and their role in metal accumulation is being elucidated to some extent.

Brassicaceae is a family that contains many types of metal accumulators. Several members of this family such as Brassica nigra, Brassica juncea, Brassica napus, and some other accumulator species like
\end{abstract}


Arabidopsis halleri and Noccaea caerulescens (formerly Thlaspi caerulescens) have attracted attention due to their huge capacity of accumulating $\mathrm{Cd}, \mathrm{Zn}, \mathrm{Cu}, \mathrm{Pb}$ and some other toxic metals and metalloids in their roots and shoots. In fact they could be suitable candidates for phytoremediation. In the coming years, the high through-put sequences technology, RNA sequence analysis and genome editing technologies will help the molecular biologists, breeders and genetists to generate new genotypes which could be highly efficient in cleanup the polluted environment. Furthermore, genetic engineering of the chloroplast genome offers a new way to obtain high expression without the risk of transgenic pollen spreading.

The aim of this review is to provide a close understanding of the molecular mechanisms of heavy metal induced plant stress response and tolerance based on the current findings related to molecular biology and biotechnology research.

Keywords: Phytoremediation, Brassica nigra, Brassica juncea, Metal transporters, Hyperaccumulator plants

DOI: $10.7176 / J S T R / 5-12-20$

\section{Bitkilerde Ağır Metal Kaynaklı Gen Ekspresyonu}

Özet

Kadmiyum $(\mathrm{Cd})$, çinko $(\mathrm{Zn})$, bakır $(\mathrm{Cu})$, krom $(\mathrm{Cr})$ ve kurşun $(\mathrm{Pb})$ gibi elementler "ağır metal" olarak kabul edilirler. Ağır metaller, endüstriyel ve beşeri faaliyetler sonucunda meydana gelen birçok etmenden dolayı biyosfere salınırlar ve ciddi boyutta çevre kirliliğine neden olurlar. Topraktaki ağır metallerin yüksek konsantrasyonları bitkinin büyümesi, gelişmesi ve ürün verimi gibi birçok olumsuz etkiye yol açar. Çevreden, bilhassa kirlenmiş toprak ve sucul alanlardan, bu kirleticilerin remediasyonu ve bu kıymetli kaynaklarımızın (su ve toprak) tekrar kullanılması açısından çevrecilere ve zirai araştırmacılarına önemli bir görev düşmektedir. Kirlenmiş alanların remediasyonu ve bu kirleticilerin potansiyel zararlı etkilerini ortadan kaldırmak için yeni ve daha ucuz teknolojiler geliştirmek önemlidir, bu gelişmeler gıda kalitesi ve insan sağ lığ 1 için doğru bir şekilde ele alınmazsa ciddi boyutlarda sorunlara yol açabilir. In situ iyileştirme tekniği olan fitoremediasyon, kirli topraklardan ve sulardan toksik metallerin uzaklaştırılabileceği en iyi yaklaşımlardan biri olabilir ve aynı zamanda kirlenmiş toprakların ve suların iyileştirilmesi için çevresel olarak sürdürülebilir ve düşük maliyetli bir yaklaşım olarak kabul edilir. Bu teknikte, toksik kirleticileri ortamda (toprak ve/veya su) yerinde iyileştirmek ve bunların köklere taşınması ve toprak üstü kısımlarda biriktirilmesini sağlayarak, kirlenmiş alandan bitkinin toprak üstü kısımlarına taşınımının gerçekleştirilmesi için genellikle hiperakümülatör bitkilerin kullanımına ihtiyaç vardır. Bununla birlikte, fitoremediasyon nispeten yeni bir teknolojidir ve bitkilerin toprak üstü kısımlarında toksik metallerin/metaloidlerin alınımı, taşınımı ve birikiminin moleküler mekanizmasının anlaşılabilmesi bakımından literatürde pek fazla araştırma mevcut değildir. Ancak son araştırmalar, bitkilerde ağır metal detoksifikasyonu, taşınımı ve birikiminde işlev gören anahtar mekanizmaların anlaşılmasında önemli gelişmeler olduğunu göstermektedir. Örneğin; translokasyon ve birikim sürecinde yer alan metal taşıyıcı genler, metal ATPaz' lar, mikroRNA' lar ve ilişkili genler tespit edilmiş ve bunların metal birikimindeki rolleri bir dereceye kadar açıklığa kavuşturulmuştur.

Brassicaceae birçok metal akümülatör içeren bir ailedir. Bu aile, örneğin; Brassica nigra, Brassica juncea, Brassica napus gibi bazı üyeleri ve Arabidopsis halleri ve Noccaea caerulescens (önceden Thlaspi caerulescens) gibi bazı diğer akümülatör türleri, köklerinde ve toprak üstü kısımlarında Cd, Zn, $\mathrm{Cu}, \mathrm{Pb}$ ve diğer bazı toksik metal/metaloidleri yüksek miktarda biriktirme kapasiteleri nedeniyle dikkati üzerlerine çekmişlerdir. Böylece bu bitki türleri fitoremediasyon için uygun adaylar olarak nitelendirilebilirler. Aynı zamanda gelecek yıllarda, yeni nesil dizileme teknolojileri, RNA dizi analizleri ve genom düzenleme teknolojileri sayesinde moleküler biyologlar, bitki 1slahçılar ve genetikçiler, kirlenmiş alanların remediasyonu için elverişli ve yüksek verime sahip yeni genotiplerin üretilmesine katkı sağlayabileceklerdir. Ayrıca, kloroplast genomunun genetik mühendisliği, transgenik polen yayılma riski olmadan aşırı seviyede anlatım için yeni bir yol sunacaktır.

Bu derlemenin amacı, moleküler biyoloji ve biyoteknoloji araştırmaları ile ilgili mevcut bulgulara dayanarak, ağır metal kaynaklı bitki stresine karşı yanıt veya tolerans mekanizmasının moleküler düzeyde daha iyi anlaşılmasına katkı sağlayacaktır.

Anahtar kelimeler: Fitoremediasyon, Brassica nigra, Brassica juncea, Metal taşıyıcılar, Hiperakümülatör bitkiler 


\section{Giriş}

Biyosferde insan faaliyetlerinin giderek artması, önemli sorunları da beraberinde getirerek, biyosferdeki kurulu dengenin ciddi bir şekilde bozulmasına yol açmaktadır. İnsan faaliyetlerinin yanı sıra kimyasal ve fosil yakıt çalışmaları, metal imalathaneleri, kâğıt fabrikaları, tabakhaneler, tekstil fabrikaları, atık bertaraf alanları ve yoğun tarım gibi endüstriyel faaliyetler de çevreyi kirleten başlıca kaynaklardır (Bhargava vd., 2012). Her bir kirlilik etmeni bitkiler, hayvanlar ve bunlara bağlı olarak insan sağlı̆̆ üzerinde zararlı etkilere neden olmaktadır, özellikle su ve toprağa ağır metalin salınımına katkı sağlayan etmenler, çevrede kalıcılık ve insanlarda kanserojen etki göstermelerinden dolayı ciddi endişe duyulanlar arasındadır. Tarım topraklarının ağır metalle kirlenmesi, potansiyel olarak olumsuz ekolojik etkileri de beraberinde getirdiği için kritik bir çevre sorunu haline gelmiş durumdadır. Bu nedenle, toksik elementler yaygın oluşumları ve kirlenmiş topraklarda yaşayan bitkilerde yol açtıkları akut ve kronik etkilerinden dolay1, öncelikli kirletici madde olarak kabul edilirler (Chaney vd., 2018). Ağır metaller, yoğunluğu 5 $\mathrm{g} / \mathrm{cm}^{3 \prime}$ ten daha yüksek olan metaller olarak tanımlanır. Doğada doğal olarak meydana gelen 90 elementten yaklaşık 43' ü ağır metaldir (Weast vd., 1988; Cevher-Keskin vd., 2019), ancak bunlardan sadece birkaçı biyolojik öneme sahiptir (Marschner, 2011). Fizyolojik koşullar altındaki çözünürlüklerine bağlı olarak, ağır metaller arasında sadece 17 tanesi, canlı hücreler tarafindan absorbe edilebilir iken, hem canlı organizma hem de ekosistem için oldukça önemli sayılabilirler (Weast vd., 1988). Böylece Fe, Mn, Zn, Cu ve Mo mikrobesin olarak önemli iken; V, Co, W ve Cr eser element olarak düşük veya yüksek öneme sahip olmaksızın toksik element olarak nitelendirilir. Diğer yandan As, Hg, $\mathrm{Ag}, \mathrm{Sb}, \mathrm{Cd}, \mathrm{Pb}$ ve $\mathrm{U}$ besin olarak bilinen bir işlevi olmadığından, bitkiler ve mikroorganizmalar için az ya da çok miktarı farketmeksizin toksik etki gösteren elementler olarak tanımlanırlar (Jenkins ve Jones, 1980; Memon vd., 2008).

İnsan faaliyetlerinden kaynaklanan metal kirliliği, doğal süreçten kaynaklanana kıyasla ciddi boyuta ulaşmış durumdadır. Örneğin; yaklaşık 13 kat $\mathrm{Cu}, 15$ kat $\mathrm{Cd}, 21$ kat $\mathrm{Zn}$ ve 100 kat daha fazla $\mathrm{Pb}$ ' nin atmosfere doğal faaliyetlere nazaran insan faaliyetleri sonucu salındığ 1983). Birçok etkili yöntem, çevreyi bu tür kirleticilerden temizlemek için kullanılır, ancak bunların çoğundan verimli sonuç almak maliyetli ve zordur. Günümüzde "fitoremediasyon" olarak tanımlanan teknik, kirlenmiş toprak ve sudan aktif metalleri veya metal kirleticileri ayrıştırmak, indirgemek veya uzaklaştırmak için kullanılan etkili ve uygun bir teknolojik çözüm haline gelmiştir (Van der Ent vd., 2018). Bu teknik için kullanılan birçok bitki türünün $\mathrm{As}, \mathrm{Pb}, \mathrm{Cd}, \mathrm{Cr}$ ve çeşitli radyonüklit gibi kirleticilerin topraklardan absorbe edilmesinde başarılı olduğu tespit edilmiştir. "Fitoekstraksiyon" olarak bilinen fitoremediasyon tekniklerinden biri, bitki gelişimi için gerekli metallerin ( $\mathrm{Fe}, \mathrm{Mn}, \mathrm{Zn}, \mathrm{Cu}, \mathrm{Mg}$, Mo ve Ni) topraktan alınımını sağlayarak, ağır metallerin topraktan uzaklaştırması için kullanılır. Ayrıca, bu teknik bitkide biyolojik fonksiyonu bilinmeyen bazı metallerin ( $\mathrm{Cd}, \mathrm{Cr}, \mathrm{Pb}, \mathrm{Co}, \mathrm{Ag}, \mathrm{Se}, \mathrm{Hg}) \mathrm{de}$ birikmesini mümkün kılabilir (Chaney ve Baklanov, 2017; Memon vd., 2001). Dolayısıyla bitkiler, ağır metale karşı olan ilgilerine göre farklı şekilde gruplandırılırlar; birinci grup hiperakümülatör (metali aşırı miktarda biriktirebilen) bitkiler (Tablo 1 bkz.), ikinci grup metale karşı hassas olanlar (hiperakümülatör olmayan metale karşı toksik etki gösteren) ve üçüncü grup ise metali bünyesine almayan (metal indikatör) bitkiler olarak bilinirler (Memon vd., 2001).

Hiperakümülatör ve hiperakümülatör olmayan türlerin, karşılaştırmalı fizyolojik ve moleküler analizinden edinilen önemli bir bulgu, hiperakümülasyon olayındaki süreçlerin her iki bitki türünde farklı mekanizmal düzenlemelere ve gen anlatımlarına dayandığı ve günümüzde bunların detaylı bir şekilde açıklığa kavuşturulması için ciddi çabalar sarf edildiğini göstermektedir. Özellikle hiperakümülatör bitkilerde, hiperakümülasyon olayının işleyiş mekanizmasının; ağır metalin yapraklara alınımı, translokasyonu ve son aşama vakuol veya hücre duvarında sekestrasyon süreçlerinin belirlenmesi ve detoksifikasyon mekanizmasında bazı önemli gen ailelerinin etken bir rol oynadığı ve bunların hiperakümülasyon olayının önemli birer parçası oldukları belirtilmiştir (Memon ve Yatazawa, 1982; Memon vd., 2001). Buna bağlı olarak, hiperakümülatörlerde ZIP, HMA, MATE, YSL ve MTP gibi transmembran taşıyıcıları kodlayan farklı gen ailelerinin aşırı anlatımı bildirilmiştir (Memon ve Schroder, 2009; Memon, 2016).

Son zamanlarda, fitoremediasyon araştırmacıları tarafından Hint hardalının (B. juncea (L.) Czern, AABB genom) $\mathrm{Zn}, \mathrm{Cd}, \mathrm{Pb}$, Se dâhil çeşitli metalleri aşırı seviyede biriktirdiği, ayrıca $B$. nigra' nın (BB genom) müthiş bir $\mathrm{Cu}$ akümülatörü olduğu bildirilmiştir (Memon ve Zahirovic, 2014; Dalyan vd., 2017; CevherKeskin vd., 2019). Bu bitkilerin metal biriktirme yetenekleri, yüksek miktarda toprak üstü biyokütle üretme potansiyelleri ile birlikte, bunları fitoekstraksiyon için ideal bir bitki yapar (Memon, 2016), böylece fitoremediasyon tekniği için müthiş potansiyele sahip bir tür olarak nitelendirilebilirler. 


\section{Fitoremediasyon}

Fitoremediasyon; bitkiler kullanılarak topraktan, sudan ve çökeltilerden kirletici maddelerin temizlenmesi işlemidir. Bu teknik, çevre dostu olmasının yanı sıra potansiyel bakımdan da uygun maliyetlidir. Ayrıca, bitkiye metalin kökler aracılığıyla seçici alınımı, bitkinin toprak üstü kısımlarına taşınımı, biyoakümülasyonu ve kirleticiyi indirgeme yeteneklerinden müthiş bir şekilde yararlanılır (Lebrun, 2001). Bu nedenle toprakta, suda veya havadaki organik veya inorganik kirleticileri gidermek amacıyla uygulanan gelişmekte olan bir teknoloji olarak tanımlanır (Chaney ve Baklanov, 2017). Ağır metali biriktirme yeteneği, türler arasında ve türler içinde önemli derecede değişiklik gösterir, çünkü her bir türün farklı iyon alım mekanizması, genetik, morfolojik, fizyolojik ve anatomik yapı özelliklerine bağlıdır. Remediasyon mekanizmasına bağlı olarak; fitoekstraksiyon, fitofiltrasyon, fitostabilizasyon, fitovolatilizasyon ve fitodegradasyon dâhil olmak üzere 5 farklı fitoremediasyon grubu mevcuttur (Memon vd., 2001; Ali vd., 2013).

Fitoekstraksiyon: Kirleticileri topraktan temizlemek için bitkilerin kullanımını içerir. Ayrıca, bitkinin hava keselerinde biriken metal iyonu, yakılarak veya imha edilerek geri kazanım amacıyla bertaraf edilebilir.

Fitofiltrasyon: Sulu çökeltilerden metallerin uzaklaştırılması için bitkinin kök veya yapraklarının kullanımını içerir.

Fitostabilizasyon: Bu durumda, bitkinin kökleri topraktan kirleticileri emer ve onları rizosferde tutar, böylece kirleticilerin sızması engellenerek zararsız hâle getirilir.

Fitovolatilizasyon: Bitki yapraklarından $\mathrm{Se}$ ve $\mathrm{Hg}$ gibi kirletici maddeleri uçucu hâle getirmek için bitkilerin kullanımını içerir.

Fitodegradasyon: Bitkiler ve onlarla ilişkili mikroorganizmaların organik kirleticileri indirgemek için kullanmasıdır (Alkorta ve Garbisu, 2001).

Fitoremediasyon tekniğinde bazı bitkiler bir işleve sahip iken, bazısı iki veya daha fazla işleve sahip olabilir (Lone vd., 2008). Toprağı kirleticilerden temizlemek için kullanılan fitoremediasyon, en ucuz ve çevre dostu biyolojik bir metot olarak kabul edilir. En yaygın ve en kârlı olanı fitoekstraksiyon, başlıca ağır metalleri ve radyoaktif elementlerin topraktan uzaklaştırılmasında kullanılır (Van der Ent vd., 2018). Fitoekstraksiyonun bağlı olduğu ana faktörler: bitki türü, bitki kökünün metal içeriği, kök tarafından metal alınımı, kökten toprak üstü kısımlara metal taşınımı ve bitkinin toksik metale karşı toleransıdır. Günümüzde bu teknik için kullanılan birçok bitki türü mevcuttur. Örneğin, toprak üstü kısımlarında yüksek miktarda $\mathrm{Zn}$ ve Cd biriktirebilen Noccaea caerulescens, Alyssum murale, A. lesbiacum ve A. tenium sayılabilir. Ancak, bu bitkilerin remediasyon potansiyeli, yavaş büyüme ve düşük biyokütle üretimleri ile sinırlandırılabilir. Diğer yandan, Brassicaceae ailesine ait birçok tür "metal akümülatör" olarak tanımlanır (Pollard vd., 2014). Bunların metal birikim mekanizmasının genetiğini tam olarak anlamak için, kullanılan model bitki Arabidopsis thaliana' da geliştirilen geniş genetik kaynaklardan faydalanılarak, model olmayan akümülatör türlerde detaylı bir şekilde metal ile ilişkili genetik haritaların oluşturulması gerekir (Reeves vd., 2017). Fitoremediasyonun daha iyi geliştirilebilmesi için bitki biyolojisi, genetik mühendisliği, toprak kimyası, toprak mikrobiyolojisi yanı sıra tarım ve çevre mühendisliği ile birleşen, bütünleşik multidisipliner araştırmaların gerçekleştirilmesine ihtiyaç bulunmaktadır (Memon ve Schroder, 2009; Chaney ve Baklanov, 2017).

\section{Ağır metal akümülatör bitkiler}

Bitki, metal alınımında seçicilik göstermesinden dolayı bünyesine bazı metallerin alınımını diğerlerine göre tercihen gerçekleştirir. Bitki için birçok ağır metal nikel (Ni), bakır $(\mathrm{Cu})$, manganez (Mn) ve çinko (Zn) gibi temel mikro besin olup, bunlar bitki büyüme ve yaşam döngüsünün tamamlaması için gereklidir (Memon vd., 2008). Dolayısıyla bitkinin ağır metale karşı duyarlılığı, fizyolojik ve moleküler meknizmaları ile ilişkili birçok ağa bağlıdır.

Örneğin;

(i) hücre dışı atıklara veya hücre duvarı bileşenlerine bağlanarak metallerin alınımı ve birikimi;

(ii) sitoplazmadan vakuollerde dâhil olmak üzere ekstra nükleer bölmelere kadar ağır metallerin akışı;

(iii) örneğin organik asitler, amino asitler, fitoşelatinler ve metallotiyoninler gibi çeşitli maddeler tarafından hücre içinde ağır metal iyonlarının kompleksleştirilmesi;

(iv) osmolit ve ozmoprotektanların birikimi, antioksidan enzimlerinin uyarılması ve

(v) metabolik yolların düzenli işleyişi ve hasarlı hücre yapılarının hızlı onarımını sağlamak için bitki metabolizmasının aktivasyonu veya modifikasyonu (Paunov vd., 2018).

Baker vd. (1981)' e göre, metal içeren topraklarda yetişen bitkiler üç kategoriye ayrılır: 
1.Dışlayıcılar (Excluders): Farklı toprak konsantrasyonlarında dâhi toprak üstü kısımlarında metal konsantrasyonunu düşük bir seviyede yani kritik bir değerde koruyabilen bitkilerdir. Dışlayıcılar, toksik metallerin kök hücrelerine alınımını önler (De Vos ve Schat, 1991). Ayrıca, dişlayıcılar toprağın stabilizasyonunu korumak ve erozyon gibi doğa olayları sonucu meydana gelen kontaminasyonun yayılımını önlemek için kullanılabilirler (Lasat, 2002).

2. Akümülatörler (Accumulators): Düşük veya yüksek metal konsantrasyonun değiştiği topraklarda, metali toprak üstü kısımlarında biriktirebilen türlerdir. Akümülatörler, metalin köklere alımını engellemez ve metalin yüksek konsantrasyonun biyolojik olarak birikimine izin verirler (Pollard vd., 2014).

3. Göstergeler (Indicators): Bitkide biriken metal konsantrasyonu ile topraktaki metal konsantrasyonu yansitan türlerdir (McGrath vd., 2002; McGrath ve Zhao, 2003). Bu nedenle, bu türler topraktaki metal miktarı için indikatör olarak kullanılabilir.

Metal akümülatör bitkilerin kirlenmiş toprağı ağır metallerden arındırılması için kullanılması, onların fitoremediasyon için geliştirilebilir müthiş bir bileşen olduklarının göstergesidir. Olağanüstü bir şekilde, metal biriktirme kapasitesine sahip bu bitkiler "hiperakümülatör bitki" olarak bilinir. Metallerce zengin bölgelerde doğal olarak yetişen hiperakümülatör bitkiler, normal bitkilere nazaran 100-1000 kat daha fazla metal biriktirebilir, çünkü bu bitkiler kirlenmemiş topraklarda yetişen bitki türlerine kıyasla topraktan iki veya üç kat daha fazla metal alabilirler (Lone vd., 2008).

\section{Hiperakümülatörler}

Bitki türleri ve onların ağır metalleri alımının yanı sıra hiperakümülasyon süreçleri ile ilişkili mekanizmaların belirlenmesinde önemli çaba gösterilmiştir. Özellikle normal bitkilere nazaran 50-500 kat daha fazla miktarda metali absorbe etme kapasitesine sahip hiperakümülatör türlerin tespiti, fitoremediasyon için önemli bir gelişme olmuştur (Lasat, 2000). Tablo 1'de görüldüğü gibi, önemli bazı metal hiperakümülatör bitkilerin listesi oluşturulmuştur. Genellikle metal içeren topraklarla sınırlı olan ve özellikle bitkinin yaprak gibi toprak üstü kısımlarında metal biriktiren hiperakümülatör bitkiler, "zorunlu (obligate) hiperakümülatör" olarak sınıflandırılırlar (Reeves vd., 2017). Diğer yandan, metal içeren veya metal içermeyen topraklarda metal biriktirebilen hiperakümülatör bitkiler ise "fakültatif hiperakümülatör" olarak sınıflandırılırlar (Pollard vd., 2014). Bu ikinci grup, sadece ultrafamik içeren topraklarda değil, aynı zamanda diğer metalle kirlenmiş topraklarda da metal biriktirebilen birçok bitki türünü içerir. Örneğin; Biscutella laevigata \%1' den fazla miktarda talyumu (Babst-Kostecka vd., 2016), Pteris vittata \%2,3'e kadar arseniği, Phytolacca americana' nın ise \%1' den fazla miktarda manganı bünyesinde biriktirebilme yeteneğinin olduğu belirtilmiştir (Xu vd., 2009). Ayrıca, bazı fakültatif hiperakümülatörler de mevcuttur. Örneğin; Acanthopanax sciadophyloides Mn zengin olmayan topraklarda yetiştirildiğinde \%1' den fazla miktarda Mn' yi yapraklarında (Memon vd., 1979; Memon ve Yatazawa, 1982); benzer şekilde, N. caerulescens ve A. halleri' nin düşük Zn içeren topraklarda yetiştirildiğinde \%1' den fazla miktarda Zn' yi yapraklarında biriktirdiği gözlemlenmiştir (Reeves vd., 2000; Stein vd., 2017).

Akümülatörler genellikle doğal mineral içeren topraklara endemik türlerdir, bu nedenle ağır metalleri toprak üstü kısımlarında herhangi bir toksisite belirtisi göstermeksizin biriktirebilme yeteneği gösterirler. Böylece bu türler Ni, Co, Cr, Cu, Al ve Pb' yi \%0,1; Zn ve Mn' yi \%1; Cd ve Se' yi de \%0,01 seviyeye kadar bünyelerinde biriktirebilirler (Baker, 2000; Baker ve Brooks, 1989). Bitkinin kirlenmiş topraklardaki ağır metal miktarını indirgemek için harcadığı zaman, biyokütle üretimi ve toprak üstü kısımlarındaki metal konsantrasyonunun topraktaki metal konsantrasyonuna oranı olarak tanımlanan biyolojik konsantrasyon faktörüne $(\mathrm{BCF})$ bağlıdır. Bu durumda, bitkinin metabolizma, büyüme ve biyokütle üretimi korunur iken, köklerin metalleri alma kapasitesi, bitkinin metalleri biriktirme, depolama ve detoksifiye etme yeteneği ile belirlenir (Gleba vd., 1999; Guerinot ve Salt, 2001; Clemens vd., 2002). Hiperakümülatörler dışında, çoğu bitkinin biyolojik konsantrasyon faktörü 1' den azdır, bu durum toprak kirliliğinin \%50 oranında indirgenmesi için insan ömründen daha uzun bir zamana ihtiyaç olduğu anlamına gelir (Peuke ve Rennenberg, 2005). Ancak, hiperakümülatörler 1' den büyük biyolojik konsantrasyon faktörüne sahiptir ve bu durum bazen 50-100' e kadar ulaşabilir. Bitkide metal hiperakümülasyon ve tolerans olayları arasındaki ilişki hâlen tartışma konusu olup; görüşler, hiperakümülatörlerin metallere karşı tolerans dereceleri arasındaki korelasyonun farklı şekillerde yorumlandığını göstermektedir (Reeves vd., 2017). Bitki, yüksek metal konsantrasyonuyla başa çıkabilmek için bünyesinde biriken metale karşı tolerans göstermesi gerektiğine dair görüşler giderek artmaktadır. Bitkide metale karşı tolerans; metal iyonunun hücre duvarına bağlanması, vakuol içine aktif taşınımı ve ardından organik asitler veya peptidler ile kompleks oluşturması gibi birçok spesifik mekanizmayı içerir (Memon vd., 2001; Memon ve Schroder, 2009). Metal hiperakümülasyonu, spesifik metalleri içeren doğal zengin habitatlarda yaşamlarını sağlayan özelleşmiş bitkilerin, artan metale karşı 
toleransı, herbivor veya patojenlere karşı korunumu, kuraklık toleransı ve allelopatinin niteliklerine sahip evrimsel bir adaptasyonun olduğuna dair uzun zamandır var olan genel bir kanı bulunmaktadır (Reeves vd., 2017). Patojen ve herbivorlara karşı korunma hipotezi, en çok kabul edilenlerden biri olarak dikkat çekmektedir (Martens ve Boyd, 1994; Huitson ve Macnair, 2003; Noret vd., 2007; Boyd ve Banzhaf, 2007; Galeas vd., 2008). Ancak, günümüzde bitkide metal alınım mekanizmasının, yani yüksek metal konsantrasyonuna karşı tolerans ve hiperakümülatörlerin hayatta kalmasında yüksek seviyede metallerin oynadığ 1 rol üzerine çalışmalar devam etmektedir. Asteraceae, Brassicaceae, Caryophyllaceae, Cyperaceae, Cunoniaceae,Fabaceae, Flacourtiaceae,Lamiaceae, Poaceae, Violaceae, ve Euphorbiaceae dâhil olmak üzere 45 angiosperm ailesinde 450' den fazla vasküler türün metal hiperakümülatör olduğu bildirilmiştir (Padmavathiamma ve Li, 2007; Reeves vd., 2017), ancak bunlar arasında özellikle Brassicaceae' ye ait Alyssum ve Thlaspi cinsleri belirtilerek, birçok metali biriktirebildikleri rapor edilmiştir (Reeves, 2000; Prasad vd., 2003; Verbruggen vd., 2009; Vamerali vd., 2010). P. vittata (Çin fren eğreltisi; uzun eğrelti), yaprak kısımlarında topraktan alınan As' nin \% $\% 95$ ' ini biriktirebilir. (Ma vd., 2001; Zhang vd., 2002). Metal hiperakümülatörü olarak en iyi bilinen angiosperm herhangi bir toksik etki göstermeksizin aşırı miktarda Zn $(39600 \mathrm{mg} / \mathrm{kg})$ ve Cd (1800 $\mathrm{mg} / \mathrm{kg}$ )'yi biriktirebilen $N$. caerulescens (pennycress) ' dir (Basic vd., 2006; Hanikenne ve Nouet, 2011; Rascio ve Navari-Izzo, 2011). Bu küçük, kendi kendine tozlaşan diploid bitki, laboratuvar koşullarında kolayca büyüyebilir, bu nedenle metal fitoekstraksiyonu ile ilişkili metal alınım, birikim ve tolerans mekanizmasının işleyişinin incelenmesinde mükemmel bir deneysel materyal olarak kullanılabilir. $N$. caerulescens dışında, $B$. juncea ve $B$. nigra da özellikle, $\mathrm{Zn}, \mathrm{Cd}$ ve $\mathrm{Cu}$ ' nun birikim fizyolojisi ve biyokimyasını araştırmak için bir model bitki olarak kullanıldığı rapor edilmiştir (Memon vd., 2001; Cevher-Keskin vd., 2019). 
International Journal of Scientific and Technological Research

ISSN 2422-8702 (Online), DOI: 10.7176/JSTR/5-12-20

Vol.5, No.12, 2019

Tablo 1. Bazı hiperakümülatörlerin listesi. Metal, sürgün/kök oranları ve metalin biriktiği dokular (Memon, Kusur, ve Memon yayımlanmamış veriler).

\begin{tabular}{|c|c|c|c|c|}
\hline Bitki türü & Metal & $\mathbf{T F}\left(\mathrm{C}_{\mathrm{s}} / \mathrm{Cr}_{\mathrm{r}}\right)$ & Doku & Kaynaklar \\
\hline A. halleri & \multirow{9}{*}{$\mathrm{Cd}$} & 0,23 & Kök & Bert vd., 2003 \\
\hline Arabis paniculata & & 1,45 & Kök, sürgün & Tang vd., 2009 \\
\hline Arabis gemmifera & & 6,13 & Sürgün & Kubota ve Takenaka, 2003 \\
\hline N. caerulescens & & - & Sürgün & Baker vd., 1994 \\
\hline T. goesingense & & 0,5 & Kök & Lombi vd., 2000 \\
\hline Noccaea praecox (T. praecox) & & - & Sürgün (5960 ppm) & Vogel-Mikuš vd., 2008 \\
\hline Sedum alfredii & & 1,05 & Kök, sürgün & Xiong vd., 2004 \\
\hline Tamarix smyrnensis & & 1,36 & Kök, sürgün & Manousaki vd., 2008 \\
\hline Rorippa globasa & & 2,21 & Sürgün & Sun vd., 2011 \\
\hline A. gemmifera & \multirow{8}{*}{$\mathrm{Zn}$} & 6,48 & Sürgün & Kubota ve Takenaka, 2003 \\
\hline A. paniculata & & 1,98 & Sürgün & Tang vd., 2009 \\
\hline T. goesingense & & - & Sürgün & Baker vd., 1994 \\
\hline N. caerulescens & & - & Sürgün & Reeves ve Brooks, 1983 \\
\hline A. halleri & & 0,16 & Kök & Küpper vd., 2000 \\
\hline S. alfredii & & 0,43 & Kök & Sun vd., 2005 \\
\hline Salix viminalis & & - & Sürgün & Schmidt, 2003 \\
\hline B. napus & & 4,02 & Sürgün & Brunetti vd., 2011 \\
\hline Aeolanthus biformifolius & \multirow{6}{*}{$\mathrm{Cu}$} & - & $\begin{array}{l}\text { Sürgün }(13700 \\
\text { ppm) }\end{array}$ & Brooks vd., 1978 \\
\hline Crassula helmsii & & - & Sürgün (9200 ppm) & Küpper vd., 2009 \\
\hline Elsholtzia splendens & & 0,033 & Kök & Weng vd., 2005 \\
\hline Sorghum sudanense L. & & 3,41 & Sürgün & Wei vd., 2008 \\
\hline $\begin{array}{l}\text { Chrysanthemum } \\
\text { coronarium } L .\end{array}$ & & 7,58 & Sürgün & Wei vd., 2008 \\
\hline B. napus & & 2,13 & Sürgün & Brunetti vd., 2011 \\
\hline Spartina argentinensis & \multirow{4}{*}{$\mathrm{Cr}$} & 5,1 & Sürgün & Redondo-Gómez, 2013 \\
\hline B. juncea & & 0,56 & Kök & Seth vd., 2012 \\
\hline B. napus & & 5,04 & Sürgün & Brunetti vd., 2011 \\
\hline A. gemmifera & & 0,15 & Kök & Kubota ve Takenaka, 2003 \\
\hline Hemidesmus indicus & \multirow{8}{*}{$\mathrm{Pb}$} & 0,66 & Kök & Sekhar vd., 2005 \\
\hline B. oleracea & & 0,54 & Kök & Zhu vd., 2004 \\
\hline Arabis paniculata & & 1,96 & Sürgün & Zeng vd., 2009 \\
\hline B. juncea & & 0,2 & Kök & Seth vd., 2012 \\
\hline N. caerulescens & & - & Sürgün $(0,66$ ppm) & Baker vd., 1994 \\
\hline S. alfredii & & 0,003 & Kök & Sun vd., 2005 \\
\hline B. napus & & 5,04 & Sürgün & Brunetti vd., 2011 \\
\hline Sesbania drummondii & & 1,1 & Kök, sürgün & Ruley vd., 2006 \\
\hline
\end{tabular}




\section{Brassicaceae}

Hardal ailesi olarak bilinen, Brassicaceae familyası (eski adıla Cruciferae), yaklaşı 375 cins ve 3200 türden oluşur. Brassica; kolza tohumu, lahana, karnabahar, brokoli, Brüksel lahanası, şalgam, çeşitli hardal ve yabani otlar da dâhil olmak üzere yaklaşık 100 tür içerir (Warwick ve Black, 1991; Özturk vd., 2012). Kültüre edilen Brassica türleri, A. thaliana ile yakın ilişkili olan tarımsal ve endüstriyel ürünlerdir. Brassicaceae üyelerinin kromozom sayıları, $2 \mathrm{n}=10$ ile $2 \mathrm{n}=38$ arasında değişir (Lysak vd., 2005). A. thaliana, $2 \mathrm{n}=10$ ile en küçük kromozom sayılarından birine sahip olup, A. lyrata ve Capsella rubella (her ikisi de $2 \mathrm{n}=16$ ) da dahil olmak üzere, aynı atadan gelmesi yanı sıra indirgenmiş gelişen bir karakter yapısına sahiptir. Genellikle "diploid" Brassica türü; B. rapa $(\mathrm{n}=10)$, B. nigra $(\mathrm{n}=8)$ ve B. oleracea $(\mathrm{n}$ = 9) olarak adlandırılan türler olup, sırasıyla A, B ve C genomlarını içerirler. Her bir çift yönlü kombinasyon kendiliğinden hibridize olarak, üç ayrı allotetraploid tür olan; B. napus (n = 19, A ve C genomlarından oluşan), $B$. juncea $\left(\mathrm{n}=18\right.$, A ve $\mathrm{B}$ genomlarından oluşan) ve $B$. carinata $^{\prime} \mathrm{y} 1(\mathrm{n}=17, \mathrm{~B}$ ve $C$ genomlarından oluşan) oluşturur. $B$. rapa ve $B$. nigra, yaklaşık $500 \mathrm{Mb}$ ile en küçük genoma sahiptir (Memon ve Zahirovic, 2014). Bu türe ait genom sekans projesi, http://www.brassicagenome.net/databases.php;

https://www.ncbi.nlm.nih.gov/genome/?term=brassica\%20napus benzeri veritabanlarında, hem sekans hem de sekans anotasyonları hâlen yürütülmektedir (Memon, 2016; Wang vd., 2016). Arabidopsis genomunun tam dizisi, Brassica türlerinin gen izolasyonu ve karakterizasyonu için en önemli kaynak hâline gelmiş olup, ayrıca Brassicaceae' nın diğer üyeleri için önemli bir referans genom olarak kullanılmaktadır. Karşılaştırmalı genomik, genom analiz ve anotasyon için güçlü bir araçtır. Arabidopsis ve Brassica' nın biyolojisi birbirine çok benzer olup, Brassicaceae türleri arasındaki genetik haritalanmanın karşılaştırılması, türlerin genom büyüklüğü, baz kromozom sayısı ve ploidi açısından farklılık gösterse de, kolineer blokları ortaya çıkarmıştır. Arabidopsis genomu, belirleyici bir genom olarak kabul edilebilir, böylece üzerine yerleştirilmiş markörler sayesinde Brassica türlerinde markörlerin karşılıklı lokalizasyonları için kullanılabilir. Genellikle Arabidopsis ve Brassica' da varsayılan ortolog genlerin ekzonları arasında \%80 ile \%90 homoloji bulunur; bu durum Arabidopsis' ten edinilen bilginin Brassica türlerinin gen izolasyonu ve karakterizasyonu ile yakından ilişkili olduğu anlamına gelir (Öztürk vd., 2012).

\section{Brassica türleri}

Brassica türleri, palmiye ve soya fasulyesi yağından sonra dünyadaki en önemli bitkisel yağ kaynağıdır. Bu bitki türleri, yüksek biyokütle üretebilme ve dokularında yüksek miktarda metal biriktirebilme veya tolere edebilme yeteneklerine sahip oldukları bilinir (Anjum vd., 2013; Kumar vd., 1995). Brassica' nın hem yağ hem de bitkisel üretim için ticari bakımdan kullanılan tarımsal olarak önemli altı türü bulunur; bunların üçü (B. nigra, B. oleracea ve B. campestris) diploittir, diğer üçü (B. juncea, B. napus, B. carinata) amfidiploittir. Bu türler arasındaki genetik çeşitlilik ve ilişkiler üçgen şeklinde tanımlanır ve literatürde "U üçgeni" olarak bilinir (Nagaharu, 1935; Özturk vd., 2012). Ayrıca, bitkide metal toleransı ve birikimi üzerine detaylı bir araştırma yapılarak, Brassica türleri arasında farklı metal birikim modelleri gözlemlenmiştir (Anjum vd., 2013; Diwan vd., 2010, Tablo 1). Bazı Brassica türleri, hem çoğu toksik metal/metaloidlere karşı yüksek toleranslı olup, hem de bu metalleri ( $\mathrm{Cd}, \mathrm{Cu}, \mathrm{Ni}, \mathrm{Pb}, \mathrm{U}, \mathrm{Zn})$ yüksek miktarda biriktirebilme özelliği gösterebilmesinden dolayı "iyi bir akümülatör tür" olarak nitelendirilirler (Kumar vd., 1995; Özturk vd., 2012). Bunlar toksik metalleri toprak üstü kısımlarında depolayabilir, bu nedenle hiçbiri toksik metaller ile ilişkili iyileştirme stratejilerinde kullanım açısından ikinci sırada yer alamaz. Brassica' nın birçok türü, yüksek miktarda biyokütle üretebildiği (fitoremediasyon için ideal bir özellik) gibi, farklı çevresel koşullara adapte de olabilir, bu nedenle seleksiyon ve rslah teknikleri ile birlikte fitoremediasyon için üstün genotipleri geliştirme potansiyeli açısından önemlidir (Anjum vd., 2012).

Brassica türlerinden biri $B$. juncea, ağır metal fitoekstraksiyon süreci ile ilişkili birçok araştırmada doğrulanarak, bu süreç için uygunluğu nedeniyle ilgileri üzerine çekmiş durumdadır. Örneğin, $B$. juncea' nın toprak üstü kısmında Cd' yi $1450 \mu \mathrm{g} / \mathrm{g}$ kuru ağırlık miktarda biriktirdiği ve bu türün Cd' yi yüksek miktarda biriktirme kapasitesine sahip olduğu rapor edilmiştir. Bu rapordan edilen sonuçlar, $B$. napus için edinilen bilgilere göre, üç kat $(555 \mu \mathrm{g} / \mathrm{g}$ kuru ağ.) daha fazla olduğu belirtilmiştir. Bununla birlikte, B. juncea $\mathrm{Pb}$ (\%28 azaltma) ve Se (\%13-48 arasında azaltma) gibi diğer metal remediasyonu içinde uygun olduğu bildirilmiştir (Szczygłowska vd., 2014). Ek olarak, Zn' nin topraktan uzaklaştırılmasında müthiş bir Zn hiperakümülatörü $N$. caerulescens' den daha etkin bir tür olduğu öne sürülmüştür. Bunun nedeni, B. juncea' nın, N. caerulescens' den 10 kat daha fazla biyokütle üretebilmesidir. Brassica' nın üç türü için; B. oleracea L., B. carinata ve B. juncea L. Czern.' nin, Zn, $\mathrm{Cu}$ ve $\mathrm{Pb}$ fitoekstraksiyon çalışmaları sırasında; en yüksek $\mathrm{Zn}$ ' yi (381 mg/kg kuru ağ.) ve $\mathrm{Cu}$ ' yu (8,34 $\mathrm{mg} / \mathrm{kg}$ kuru ağ.), B. oleracea L.' nin toprak üstü kısımlarında biriktirdiği rapor edilmiştir. Tüm Brassica 
türlerinin biriktirdiği $\mathrm{Pb}$ ' yi, diğer metallere nazaran daha düşük değerlere sahip olması ile birlikte, bu türlerin $\mathrm{Pb}$ ' yi birikim oranları ise sabittir. $\mathrm{Bu}$ durum, $\mathrm{Pb}^{\prime}$ nin düşük biyoakümülasyonu aşırı çözünmezliğinden kaynaklanmakta olup, genellikle normal toprak pH aralığının bitki alınımı için uygun olmadığını gösterir (Anjum vd., 2013; Szczygłowska vd., 2014). Ayrıca, Güneydoğu Anadolu’ da birçok endemik metal akümülatör bitki türü bildirilmiş, bunlardan özellikle Diyarbakır Bölgesi' nde yetişen $B$. nigra ekotipinin toprak üstü kısımlarında aşırı miktarda $\mathrm{Cu}^{\prime}$ yu (yapraklarında yaklaşık $700 \mathrm{ppm} \mathrm{Cu}$ ) biriktirdiği tespit edilmiştir. Bu ekotip bitki, kallus kültüründen rejenere edildiğinde ve $500 \mu \mathrm{M} \mathrm{Cu}$ içeren toprak kültüründe yetiştirildiğinde, toprak üstü kısımlarında köklere kıyasla 3 kat daha fazla $\mathrm{Cu}^{\prime}$ yu (yaklaşık $20000 \mu \mathrm{g} / \mathrm{g}$ kuru ağırlık) biriktirdiği bildirilmiştir (Memon ve Zahorovic, 2014). Bu sonuçlar, B. nigra' nın "Cu akümülatörü" olarak ilk defa belirtildiğini göstermektedir. Dolayısıyla, Brassicaceae ailesinden, birçok türün yüksek metal birikim kapasitesi, özellikle $B$. juncea ve $B$. nigra' nın kirlenmiş topraktan $\mathrm{Zn}, \mathrm{Cu}, \mathrm{Cd}$ ve $\mathrm{Pb}$ gibi farklı metallerin fitoremediasyonu için ideal türler olabilecekleri anlamını taşımaktadır (Kumar vd., 2012).

\section{Ağır metal alınımı, birikimi ve hücresel lokalizasyonu}

Tarımsal bitkilerin çoğu, metabolizma ve normal büyüme faaliyetleri için genellikle 10 ile 15 ppm arasında değişen miktarlarda mikro besinlere gereksinim duyarlar. Diğer bir yandan, "hiperakümülatör" olarak adlandırılan bazı bitkiler ise bünyelerine herhangi bir toksisite belirtisi göstermeksizin binlerce ppm seviyedeki toksik metalleri alabilme yeteneği sergilerler. Bu akümülatörlerin metal toksisitesi ile nasıl başa çıktıkları ve metal toksisitesinden nasıl kaçındıkları halen merak uyandıran bir araştırma konusudur. Diğer bir merak uyandıran konu ise, bunların toksik metalleri zararsız hâle getirmedeki sorumlu mekanizmalarının neler olduğudur. Birçok mekanizmanın rol oynadığ 1 söz konusu olup, özellikle vakuolde depolama, metal detoksifikasyonunun en önemli mekanizmalarından biri olduğu belirtilmiştir (Memon vd., 2001; Reeves vd., 2017). Malat, sitrat, histidin gibi organik asit şelatörleri (Salt vd. 1995; Von Wirén vd., 1999) veya nikotinamid (1996; Von Wirén vd., 1999) gibi farklı tür şelatörlerin, metal katyonların ksilem yoluyla translokasyonuna katıldığı bildirilmiştir. Metal, bir şelatla kompleks oluşturduğunda ksilemin daha yüksek katyon değişim kapasitesi tarafindan adsorbe edilmeden direkt olarak ksilemde yukarı doğru taşınabilir (Von Wirén vd., 1999).

Metalle kirlenmiş topraklarda yaşayan bitkilerin çeşitli metal tolerans ve birikim mekanizmalara sahip olduğu öne sürülmüştür (Memon ve Schröder, 2009; Memon, 2016). Bitkide hiperakümülasyon mekanizması, metalin köklerden verimli bir şekilde alınımı, köklerden ksilem boyunca toprak üstü kısımlara taşınımı ve daha sonra hücre içi bölmelerinde kompleksleştirilmesi ve sekestre edilmesi veya trikomlarda salgılanmasını içeren müthiş bir düzenin bulunduğu ve bu mekanizmanın metal homeostaz ağının bir parçası olduğu belirtilmiştir (Memon ve Schröder, 2009; Hanikenne ve Nouet, 2011; Ovečka ve Takáč, 2014). Bu akümülatörler, müthiş bir ekofizyolojik karaktere sahip olduklarından; toprak üstü kısımlara ve yapraklara yüksek miktarda metal alma, taşıma, biriktirme yeteneği gösterir, ayrıca onları hücre duvarında, vakuolde ve sitozoldeki diğer hücre içi alt bölmelere aktararak, hücredeki metabolik aktivitelerden uzak tutulmasını sağlayabilirler (Memon ve Yatazawa, 1982; Memon ve Schröder, 2009). A. sciadophylloides ve çay yapraklarında Mn'nin hücre içi lokalizasyonlarını belirlemek için elektroprob $\mathrm{X}$-1şını mikro analizi, sıvı azot içerisinde dondurulan taze yaprak örnekleri kullanılarak gerçekleştirilmiştir. Mn' nin hücre içi düzeydeki mikrodağılım profili, genellikle $\mathrm{Mn}^{\prime}$ nin hücre duvarı ve epidermal hücrelerin vakuol bölmelerinde biriktiği, böylece metabolik olarak aktif bölmelerden örneğin sitozol, mitokondri ve kloroplasttan uzak tutulduğu gösterilmiştir (Memon vd., 1982). Şekil 1' de, çay yaprağında Mn' nin hücre içi lokalizasyonu gösterilmektedir. Sonuçlar incelendiğinde, genellikle Mn' nin, hücre duvarında ve epidermal hücrelerin vakuollerinde biriktiği ve sitoplazmada neredeyse yok denecek kadar az miktarda olduğu tespit edilmiştir. 


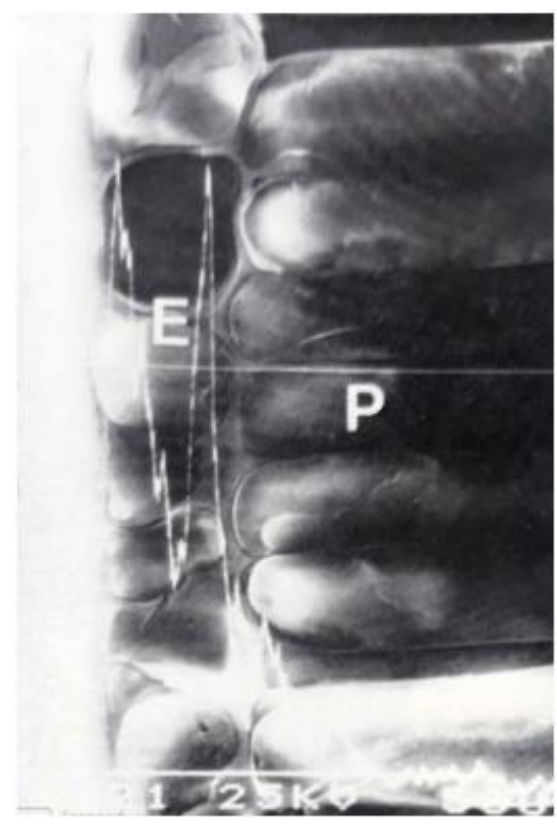

Şekil 1. Çay yapraklarında Mn' nin sekonder elektron mikrograf ( $\mathrm{K} \alpha$ radyasyonu) çizgi tarama profili. Mn' nin subsellüler seviyede epidermis hücrelerindeki lokalizasyonu. E, epidermis; $P$, palizat parankimasi hücreleri (Memon vd., 1982).

Hiperakümülatör bitkiler, hücredeki ağır metal toksisitesini indirgemek veya detoksifiye etmek için müthiş spesifik mekanizmalar geliştirmiştir. Daha önce de belirtildiği gibi, hücredeki metalin toksisitesini indirgemenin en etkili yolu, onu farklı hücre içi bölmelere ayırarak, sitoplazmadaki metabolik süreçten uzak tutmaktır. Bitkiler bu işlemi, hücre duvarı ve/veya vakuol olmak üzere hücrenin aktif olmayan bölmelerinde metalleri ayırarak gerçekleştirir (Memon vd., 1982; Memon ve Yatazawa, 1984).

A. sciadophylloides (Frach. ve Sav.) yaprakları ile gerçekleştirilen hücre parçalanma (fraksiyon) analiz sonucu, Mn' nin büyük bir kısmının hücre duvarında ve süpernatantta (üst bölmede) mevcut olduğu, ayrıca parçalanma aşamasında süpernatantta yüksek miktarda Mn' nin, bir organik asit (yaklaşık 145 g/mol moleküler ağırlığa sahip) ile kompleks oluşturduğunu göstermiştir (Memon ve Yatazawa, 1984). Mn2+' nin sitoplazmada malat ile kompleksinin daha sonra malattan ayrılarak, oksalat ile kararlı bir kompleks oluşturmak için vakuole taşındığı öne sürülmüştür. Bu durumda, sitoplazma boyunca malatın "taşıma aracı", vakuolde ise okzalatın "terminal alıcı" olarak işlev gördüğü belirtilmiştir (Memon ve Yatazawa, 1984; Memon ve Schröder, 2009). Ayrıca, çeşitli enzimatik antioksidanlar, örneğin; süperoksit dismutaz, peroksidaz, katalaz, glutatyon redüktaz ve non-enzimatik antioksidanlar (örneğin, flavonoidler, indirgenen glutatyon, askorbik asit), hem ROS' un neden olduğu serbest radikalleri nötralize etmede hem de bitki hasarını en aza indirgemede önemli bir rol oynar (Küpper vd., 1999; Van de Mortel vd., 2008; Li vd., 2015). Dolayısıyla, metal ve bitki türüne bağlı olarak, bitkide metal detoksifikasyon ve birikim için farklı birçok mekanizma öne sürülmüştür (Rascio ve Navari-Izzo, 2011; Isaure vd., 2015; Memon,2016,). Buna ilaveten, fitoşelatinler, metallotiyoninler, metaloenzimler, metalle aktifleşen enzimler ve çeşitli kanal proteinlerinin metalleri bağladığ 1 ve sekestre ettiği bildirilmiştir (Hanikenne ve Nouet, 2011; Isaure vd., 2015; Memon, 2016). Bu nedenle, yeni nesil dizileme teknolojiler; transkriptomik (mikrodizi analizi, RNA dizi analizi), proteomik ve metabolomik gelişmeler, hücre ortamda yüksek metal konsantrasyonuna maruz kaldığında hücredeki farklı genlerin, proteinlerin ve metabolitlerin işlevi ve düzenlenmesinin daha detaylı bir şekilde anlaşılabilmesi için yeni bir kaynak sağlayacaktır (Verbruggen vd., 2013).

\section{Sonuç}

$\mathrm{Bu}$ derlemede, fitoremediasyon alanındaki son gelişmeler özetlenmiştir. Zorunlu ve fakültatif hiperakümülatör türler tanımlanarak, bunların metal birikimindeki rolleri açıklanmıştır. Hiperakümülatör bitkilerin yaprak hücrelerindeki metal dağılımı ve lokalizasyonu X-1şını mikroprob analizörü ile analiz edilmiş, bunların hücre içi dağılım şekilleri incelenmiştir. Dünya çapındaki hiperakümülatör veritabanı (www.hyperaccumulators.org), yakın zamanda Avustralya' daki Queensland Üniversitesi' nin Center for Mined Land Rehabilitation (CMLR; Maden Arazisi Rehabilitasyon Merkezi) tarafindan kurulmuştur. 
Veritabanı ücretsiz olarak erişime açıktır ve biyologlar, çevreciler ve moleküler biyologların araştırmaları için faydalı olabilecek bilinen tüm metal/metaloid hiperakümülatör türlerin, taksonomisi, dünya çapında dağılımı, ekolojisi, analitik verileri ve diğer ilişkili bilgileri içerir. B. rapa ve B. napus' un genom analizlerinde son gelişmeler, toprakta yüksek metal konsantrasyonuna maruz bırakıldıklarında, birçok farklı metal taşıyıcının anlatımının olduğunu göstermiştir. Bunlar, iyi bilinen dikot (çift çenekli) tür A. thaliana ve monokot tür Oryza sativa verileri ile karşılaştırılmıştır. Akümülatör bitkilerde farklı metal tasıyıcıların örneğin, ZIP, MTP, NRAMP, ABC ve HMA' lar da dâhil olmak üzere metal taşıyıcıların fonksiyonel analizi üzerinde durulmuştur. Ayrıca, bu derlemede, hiperakümülatör bitkilerin metal birikim ve detoksifikasyon mekanizmasındaki metal taşıyıcıların rolü ve bunların fitoremediasyon tekniğindeki işlevleri hakkında bilgi verilmiştir.

\section{Referanslar}

Ali, H., Khan, E., ve Sajad, M. A. (2013). Phytoremediation of heavy metals-concepts and applications. Chemosphere, 91(7), 869-881.

Alkorta, I., ve Garbisu, C. (2001). Phytoremediation of organic contaminants in soils. Bioresource Technology, 79(3), 273-276.

Anjum, N. A., Ahmad, I., Pereira, M. E., Duarte, A. C., Umar, S. ve Khan, N. A. (2012). The Plant Family Brassicaceae: Contribution Towards Phytoremediation(1st ed.) Springer Dordrecht, The Netherlands, (Chapter 1).

Anjum, N. A., Gill, S. S., Duarte, A. C., Pereira, E. ve Ahmad, I. (2013). Silver nanoparticles in soilplant systems. Journal of Nanoparticle Research, 15(9), 1896.

Babst-Kostecka, A. A., Waldmann, P., Frérot, H. ve Vollenweider, P. (2016). Plant adaptation to metal polluted environments - physiological, morphological, and evolutionary insights from Biscutella laevigata. Environmental and Experimental Botany, 127, 1-13.

Baker, A.J.M. ve Brooks, R.R. (1989).Terrestrial Higher Plants which Hyperaccumulate Metallic Elements-A Review of Their Distribution, Ecology and Phytochemistry. Biorecovery, 1(2), 81126.

Baker, A.J.M., (1981). "Accumulators and excluders strategies in the response of plants to heavy metals", Journal of Plant Nutrition, 3: 643-654.

Baker, A.J.M., Reeves R.D. ve Hajar A.S.M. (1994). Heavy metal accumulation and tolerance in British populations of the metallophyte Thlaspi caerulescens. New Phytologist; 127, 61-68.

Baker, A.J.M., McGrath, S., Reeves, R. ve Smith, J.A.C. (2000). Metal hyperaccumulator plants: a review of the ecology and physiology of a biological resource for phytoremediation of metalpolluted soils. Phytoremediation of contaminated soil water.

Basic, N, Salamin, N, Keller, C, Galland, N. ve Besnard, G. (2006). Cadmium hyperaccumulation and genetic differentiation of Thlaspi caerulescens populations. Biochemical Systematics and Ecology, 34(9), 667-677.

Bhargava, A., Carmona, F. F., Bhargava, M. ve Srivastava, S. (2012). Approaches for enhanced phytoextraction of heavy metals.Journal of Environmental Management, 105, 103-120.

Bert, V., Meerts, P., Saumitou-Laprade, P., Salis, P., Gruber, W. ve Verbruggen, N. (2003). Genetic basis of Cd tolerance and hyperaccumulation in Arabidopsis halleri, Plant and Soil, 249(1), 918.

Boyd, J., ve Banzhaf, S. (2007). What are ecosystem services? The need for standardized environmental accounting units. Ecological Economics, 63(2-3), 616-626. 
Brunetti, G., Farrag, K., Soler-Rovira, P., Nigro, F. ve Senesi, N. (2011). Greenhouse and Field Studies on $\mathrm{Cr}, \mathrm{Cu}, \mathrm{Pb}$ and $\mathrm{Zn}$ Phytoextraction by Brassica napus from Contaminated Soils in the Apulia Region, Southern Italy. Geoderma, 160, 517-523.

Brooks, R.R., Morrison, R.S., Reeves, R.U. ve Malaisse, F. (1978). Copper and cobalt in African species of Aeolanthus Mart. (Plectranthinae, Labiatae). Plant and Soil, 50(1-3), 503-507.

Campbell, P., Stokes, P. ve Galloway, J. (1983). Effects of atmospheric deposition on the geochemical cycling and biological availability of metals. Heavy Metals in the Environment, 2, $760-763$.

Cevher-Keskin, B., Yildizhan, Y., Yuksel, B., Dalyan, E. ve Memon, A.R. (2019). Characterization of differentially expressed genes to $\mathrm{Cu}$ stress in Brassica nigra by Arabidopsis genome arrays. Environmental Science and Pollution Research, 26(1), 299-311.

Chaney, R.L., Baker, A.J.M. ve Morel, J.L. (2018). The Long Road to Developing Agromining/Phytomining. In: Van der Ent A., Echevarria G., Baker A.J.M., Morel J. (eds) Agromining: Farming for Metals. Mineral Resource Reviews. Springer, Cham

Chaney, R.L. ve Baklanov, I.A. (2017). Phytoremediation and phytomining: status and promise. In Advances in botanical research (Vol. 83, pp. 189-221): Elsevier.

Clemens, S., Palmgren, M. G. ve Kramer, U. (2002). A long way ahead: understanding and engineering plant metal accumulation. Trends in Plant Science, 7(7), 309-315.

Dalyan, E., Yüzbaşığlu, E., Keskin, B.C., Yıldızhan, Y., Memon, A., Ünal, M. ve Yüksel, B. (2017). The identification of genes associated with $\mathrm{Pb}$ and $\mathrm{Cd}$ response mechanism in Brassica juncea L. By using Arabidopsis expression array. Environmental and Experimental Botany, 139, 105115.

De Vos, C. ve Schat, H. (1991). Free radicals and heavy metal tolerance. In Ecological responses to environmental stresses (pp. 22-31): Springer.

Diwan, H., Khan, I., Ahmad, A. ve Iqbal, M. (2010). Induction of phytochelatins and antioxidant defence system in Brassica juncea and Vigna radiata in response to chromium treatments. Plant Growth Regulation, 61(1), 97-107.

Galeas, M.L., Klamper, E.M., Bennett, L.E., Freeman, J.L., Kondratieff, B.C., Quinn, C.F. ve PilonSmits, E.A. (2008). Selenium hyperaccumulation reduces plant arthropod loads in the field. New Phytologist, 177(3), 715-724.

Gleba, D., Borisjuk, N.V., Borisjuk, L.G., Kneer, R., Poulev, A., Skarzhinskaya, M., Dushenkov, S., Logendra, S., Gleba, Y.Y., Raskin, I. (1999). Use of plant köks for phytoremediation and molecular farming. Proceedings of the National Academy of Sciences of the United States of America, 96(11), 5973-5977.

Guerinot, M. L. ve Salt, D. E. (2001). Fortified foods and phytoremediation. Two sides of the same coin. Plant Physiology, 125(1), 164-167.

Hanikenne, M. ve Nouet, C. (2011). Metal hyperaccumulation and hypertolerance: a model for plant evolutionary genomics. Current OpinioninPlant Biology, 14(3), 252-259.

Huitson, S. B. ve Macnair, M. R. (2003). Does zinc protect the zinc hyperaccumulator Arabidopsis halleri from herbivory by snails? New Phytologist, 159(2), 453-459. 
Isaure M.P., Huguet, S., Meyer, C.L., Castillo-Michel, H., Testemale, D., Vantelon, D., SaumitouLaprade, P, Verbruggen, N. ve Sarret, G. (2015). Evidence of various mechanisms of Cd sequestration in the hyperaccumulator Arabidopsis halleri, the non-accumulator Arabidopsis lyrata, and their progenies by combined synchrotron-based techniques.Journal of Experimental Botany, 66(11), 3201-3214

Jenkins, D. ve Jones, R. W. (1980). Applied soil trace elements (B. E. Davies Ed.).

Kubota, H. ve Takenaka, C. (2003). Field Note: Arabis gemmifera is a Hyperaccumulator of Cd and Zn. International Journal of Phytoremediation. 5, 197-201.

Kumar, P. N., Dushenkov, V., Motto, H. ve Raskin, I. (1995). Phytoextraction: the use of plants to remove heavy metals from soils. Environmental Science \& Technology, 29(5), 1232-1238.

Kumar, V., Mahajan, M. ve Yadav, S.K. (2012). The Plant Family Brassicaceae: Contribution Towards Phytoremediation(1st ed.) Springer Dordrecht, The Netherlands, (Chapter 7).Toxic metals accumulation, tolerance and homeostasis in brassicaoilseed species: Overview of physiological, biochemical and molecular mechanisms. 171-211.

Küpper, H., Zhao, F.J. ve McGrath S.P. (1999). Cellular Compartmentation Of Zinc In Leaves Of The Hyperaccumulator Thlaspi caerulescens.Plant Physiology, 119(1), 305-312.

Küpper, H., Lombi, E, Zhao, F.J. ve McGrath S.P. (2000). Cellular compartmentation of cadmium and zinc in relation to other elements in the hyperaccumulator Arabidopsis halleri, Planta, 212(1), 75-84.

Küpper, H., Götz, B., Mijovilovich, A., Küpper, F.C. ve Meyer-Klaucke, W. (2009). Complexation and toxicity of copper in higher plants. I. Characterization of copper accumulation, speciation, and toxicity in Crassula helmsii as a new copper accumulator.Plant Physiology, 151(2), 702-714.

Lasat, M.M. (2000). Use of plants for the removal of toxic metals from contaminated soil: $U S$ Environmental Protection Agency.

Lasat, M.M. (2002). Phytoextraction of toxic metals: a review of biological mechanisms. Journal of Environmental Quality, 31(1), 109-120.

Lebrun, M. (2001). Phytoremediation of Toxic Metals. Using Plants to Clean Up the Environment, Edited by I. Raskin and B. Ensley, John Wiley ve Sons, Inc., New York, 2000. ISBN 0-47119254-6; 304 pp. Plant Science, 5(160), 1073-1075.

Li, Xu, X., Hu, X., Liu, Q., Wang, Z., Zhang, H., Wang, H., Wei, M., Wang, H., Liu, H. ve Li, C. (2015). Genome-wide analysis and heavy metal-induced expression profiling of the HMAgene family in Populus trichocarpa.Frontiers In Plant Science, 6,1149.

Lombi E., Zhao, F.J., Dunham, S.J. ve McGrath, S.P., (2000), Cadmium accumulation in populations of Thlaspi caerulescens and Thlaspi goesingense. The New Phytologist, 145(1), 11-20.

Lone, M.I., He, Z.L., Stoffella, P.J. ve Yang, X.E. (2008). Phytoremediation of heavy metal polluted soils and water: progresses and perspectives. Journal of Zhejiang University Science B, 9(3), 210 220.

Lysak, M. A., Koch, M. A., Pecinka, A. ve Schubert, I., (2005). Chromosome triplication found across the tribe Brassicaceae. Genome Research, 15(4), 516-525.

Ma, L., Komar, K., Tu, C., Zhang, W., Cai, Y. ve Kennelley, E., (2001). A fern that hyperaccumulates arsenic. Nature, 411(6836), 438. 
Manousaki, E., Kadukova. J., Papadantonakis, N. ve Kalogerakis, N. (2008). Phytoextraction and phytoexcretion of $\mathrm{Cd}$ by the leaves of Tamarix smyrnensis growing on contaminated non-saline and saline soils. Environmental Research, 106(3), 326-332.

Marschner, H. (2011). Marschner's mineral nutrition of higher plants (3rd ed.): Academic press.

Martens, S. N. ve Boyd, R. S. (1994). The ecological significance of nickel hyperaccumulation: a plant chemical defense. Oecologia, 98(3-4), 379-384.

McGrath, S., Zhao, J. ve Lombi, E. (2002). Phytoremediation of metals, metalloids, and radionuclides (Vol. 75)

McGrath, S.P. ve Zhao, F.J. (2003). Phytoextraction of metals and metalloids from contaminated soils. Current Opinion in Biotechnology, 14(3), 277-282.

Memon, A.R. (2016). Metal Hyperaccumulators: Mechanisms of Hyperaccumulation and Metal Tolerance. In Phytoremediation (pp. 239-268): Springer.

Memon, A.R., Aktoprakligil, D., Ozdemir, A. ve Vertii, A. (2001). Heavy metal accumulation and detoxification mechanisms in plants. Turkish Journal of Botany, 25(3), 111-121.

Memon, A.R., Itô, S. ve Yatazawa, M. (1979). Absorption and accumulation of iron, manganese and copper in plants in the temperate forest of central Japan. Soil Science Plant Nutrition, 25(4), 611 620.

Memon, A.R. ve Schroder, P. (2009). Implications of metal accumulation mechanisms to phytoremediation. Environmental Science and Pollution Research, 16(2), 162-175.

Memon, A.R. ve Yatazawa, M. (1982). Chemical 192atüre of manganese in the leaves of manganese accumulator plants. Soil Science Plant Nutrition, 28(3), 401-412.

Memon, A.R. ve Yatazawa, M. (1984). Nature of manganese complexes in manganese accumulator plant -Acanthopanax sciadophylloides. Journal of Plant Nutrition, 7(6), 961-974.

Memon, A.R., Yildizhan, Y. ve Kaplan, E. (2008).Trace Elements As Contaminants And Nutrients (Chapter 4). Wiley, New Jersey, USA.Metal Accumulation in Crops-Human Health Issues. 8193

Memon, A.R. ve Zahirovic, E. (2014). Genomics and Transcriptomics Analysis of Cu Accumulator Plant Brassica nigra L.Journal of Applied Biological Sciences, 8(2), 1-8.

Nagaharu, U. (1935). Genome analysis in Brassica with special reference to the experimental formation of B. napus and peculiar mode of fertilization. Japanese Journal of Botany, 7(7), 389452.

Noret, N., Meerts, P., Vanhaelen, M., Dos Santos, A. ve Escarré, J. (2007). Do metal-rich plants deter herbivores? A field test of the defence hypothesis. Oecologia, 152(1), 92-100.

Özturk, M., Memon, A.R., Gucel, S. ve Sakcali, M.S. (2012). Brassicas in Turkey and Their Potential Role for Degraded Habitats' Remediation.The Plant Family Brassicaceae (pp. 265-287): Springer.

Ovečka, M. ve Takáč, T.J. (2014). Managing heavy metal toxicity stress in plants: biological and biotechnological tools. Biotechnology Advances, 32(1), 73-86.

Padmavathiamma, P. K. ve Li, L. Y. (2007). Phytoremediation technology: hyper-accumulation metals in plants. Water, Air, Soil Pollution, 184(1-4), 105-126. 
Paunov, M., Koleva, L., Vassilev, A., Vangronsveld, J. ve Goltsev, V. (2018). Effects of Different Metals on Photosynthesis: Cadmium and Zinc Affect Chlorophyll Fluorescence in Durum Wheat. International Journal of Molecular Sciences, 19(3), 787.

Peuke, A.D. ve Rennenberg, H. (2005). Phytoremediation: molecular biology, requirements for application, environmental protection, public attention and feasibility. EMBO reports, 6(6), 497501.

Pollard, A.J., Reeves, R.D. ve Baker, A.J.M. (2014). Facultative hyperaccumulation of heavy metals and metalloids. Plant Science, 217-218, 8-17.

Rascio, N. ve Navari-Izzo, F. (2011). Heavy metal hyperaccumulating plants: how and why do they do it? And what makes them so interesting? Plant Science, 180(2), 169-181.

Redondo-Gómez, S. (2013). Bioaccumulation of heavy metals in Spartina. Functional Plant Biology, 40(9), 913-921.

Reeves, R.D. ve Baker, A.J.M., (2000). Metal accumulating plants. In: Raskin, I. and Finsley, B.D., Eds., Phytoremediation of Toxic Metals: Using Plants to Clean up the Environment, Wiley, New York, 193-229.

Reeves, R.D., Baker, A.J.M., Jaffré, T., Erskine, P.D., Echevarria, G. ve Van der Ent, A. (2017). A global database for plants that hyperaccumulate metal and metalloid trace elements. New Phytologist, 218(2), 407-411.

Reeves, R.D. ve Brooks, R.R. (1983). European species of Thlaspi L. (Cruciferae) as indicators of nickel and zinc. Journal of Geochemical Exploration, 18(3), 275-283.

Ruley, A.T., Sharma, N.C., Sahi, S.V., Singh, S.R., Sajwan, K.S. (2006). Effects of lead and chelators on growth, photosynthetic activity and $\mathrm{Pb}$ uptake in Sesbania drummondii grown in soil.Environmental Pollution, 144(1), 11-18.

Salt, D.E., Blaylock, M., Kumar, N.P., Dushenkov, V., Ensley, B.D., Chet, I. ve Raskin, I. (1995). Phytoremediation: a novel strategy for the removal of toxic metals from the environment using plants. Biotechnology (N Y), 13(5), 468-474.

Schmidt, U. (2003). Enhancing Phytoextraction, Journal of Environmental Quality, 32(6), 19391954.

Sekhar, K.C., Kamala, C.T., Chary, N.S. ve Balaram, V. (2005). Potential of Hemidesmus indicus for phytoextraction of lead from industrially contaminated soils. Chemosphere, 58(4), 507-514.

Seth, C.S., Misra, V. ve Chauhan, L.K. (2012). Accumulation, detoxification, and genotoxicity of heavy metals in Indian mustard (Brassica juncea L.). International Journal of Phytoremediation, 14(1), $1-13$

Stein, R.J., Höreth, S., de Melo, J.R.F., Syllwasschy, L., Lee, G., Garbin, M.L., Clemens, S. ve Kramer, U., (2017), Relationships between soil and leaf mineral composition are element-specific, environment-dependent andgeographically structured in the emerging modelArabidopsis halleri. New Phytologist, 213:1274-1286.

Sun, Y., Zhou, Q., Xu,Y., Wang,L. ve Liang, X. (2011). The role of EDTA on cadmium phytoextraction in a cadmium-hyperaccumulator Rorippa globosa.Journal of Environmental Chemistry and Ecotoxicology, 3(3), 45-51. 
Sun, Q., Ye, Z.H., Wang, X.R. ve Wong M.H. (2005). Increase of glutathione in mine population of Sedum alfredii: A Zn hyperaccumulator and $\mathrm{Pb}$ accumulator. Phytochemistry, 66(21), 2549-2556.

Szczygłowska, M., Bodnar, M., Namieśnik, J. ve Konieczka, P. (2014). The use of vegetables in the biomonitoring of cadmium and lead pollution in the environment. Critical Reviews in Analytical Chemistry, 44(1), 2-15.

Tang, Y.T., Qiu, R., Zeng, X.W., Ying, R.R., Yu, F.M. ve Zhou, X.Y., (2009). Lead, zinc, cadmium hyperaccumulation and growth stimulation in Arabis paniculata Franch. Environmental and Experimental Botany. 66(1), 126-134.

Vamerali, T., Bandiera, M. ve Mosca, G. (2010). Field crops for phytoremediation of metalcontaminated land. A review. Environmental Chemistry Letters, 8(1), 1-17.

Van De Mortel, J.E., Schat, H., Moerland, P.D., Verloren Van Themaat, E., Van der Ent, S., Blankestijn, H., Ghandylian, A., Tsiasiani,S. ve Aarts, M.G.M., (2008). Expression differences for genes involved in lignin, glutathione and sulphate metabolism in response to cadmium in Arabidopsis thaliana and the related $\mathrm{Zn} / \mathrm{Cd}$-hyperaccumulator Thlaspi caerulescens.Plant, Cell and Environment, 31(3), 301-324.

Van der Ent, A., Echevarria, G., Baker, A.J.M. ve Morel, J.L. (2018). Agromining: Farming for Metals Extracting Unconventional Resources Using Plants Preface.

Vara Prasad, M. N. ve de Oliveira Freitas, H. M., (2003). Metal hyperaccumulation in plants: biodiversity prospecting for phytoremediation technology. Electronic Journal of Biotechnology, 6(3), 285-321.

Verbruggen, N., Hermans, C. ve Schat, H. (2009). Molecular mechanisms of metal hyperaccumulation in plants. New Phytologist, 181(4), 759-776.

Verbruggen, N., Hanikenne, M. ve Clemens, S. (2013). A more complete picture of metal hyperaccumulation through next-generation sequencing technologies. Frontiers in Plant Science, $4,388$.

Vogel-Mikuš,K., Simcic, J., Pelicon, P., Budnar, M., Kump, P., Necemer, M., Mesjasz-Przybyłowicz, J., Przybyłowicz, W.J. ve Regvar, M.(2008). Comparison of essential and non-essential element distribution in leaves of the $\mathrm{Cd} / \mathrm{Zn}$ hyperaccumulator Thlaspi praecox as revealed by micro-PIXE. Plant, Cell and Environment, 31(10), 1484-1496.

Von Wirén N., Klair, S., Bansal, S., Briat, J.F., Khodr, H., Shioiri, T., Leigh, R.A. ve Hider, R.C. (1999). Nicotianamine chelates both FeIII and FeII. Implications for metal transport in plants. Plant Physiology, 119(3), 1107-1114.

Wang, Z., Gresch, D., Soluyanov, A. A., Xie, W., Kushwaha, S., Dai, X., Troyer, M., Cava, R.J. ve Bernevig, B.A. (2016). MoTe2: A Type-II Weyl Topological Metal. Physical Review Letters, 117(5), 056805.

Warwick, S. I. ve Black, L. D. (1991). Molecular systematics of Brassica and allied genera (subtribe Brassicinae, Brassiceae)-chloroplast genome and cytodeme congruence. Theoretical and Applied Genetics, 82(1), 81-92.

Weast, R. C., Astle, M. J. ve Beyer, W. H. (1988). CRC handbook of chemistry and physics (Vol. 69): CRC press Boca Raton, FL.

Wei, L., Luo, C., Li, X. ve Shen, Z. (2008). Copper Accumulation and Tolerance in Chrysanthemum coronarium L. and Sorghum sudanense L.Archives of Environmental Contamination and Toxicology, 55(2), 238-246. 
Weng, G., Wu, L., Wang, Z., Luo, Y. ve Christie, P. (2005). Copper uptake by four Elsholtzia ecotypes supplied with varying levels of copper in solution culture. Environment International, 31(6), 880884.

Xiong, Y.H., Yang, X.E., Ye, Z.Q. ve He, Z.L., (2004). Characteristics of cadmium uptake and accumulation by two contrasting ecotypes of Sedum alfredii Hance. Journal of Environmental Science and Health. Part A, Toxic/hazardous Substances \& Environmental Engineering, 39(1112),2925-2940.

Xu, X., Shi, J., Chen, X., Chen, Y. ve Hu, T. (2009). Chemical forms of manganese in the leaves of manganese hyperaccumulator Phytolacca acinosa Roxb.(Phytolaccaceae). Plant and Soil, 318(12), 197.

Zeng, X., Ma, L.Q., Qiu, R. ve Tang, Y.(2009). Responses of non-protein thiols to Cd exposure in Cd hyperaccumulator Arabis paniculata Franch. Environmental and Experimental Botany, 66(2), 242-248.

Zhang, W., Cai, Y., Tu, C. ve Ma, L.Q. (2002). Arsenic speciation and distribution in an arsenic hyperaccumulating plant. Science of The Total Environment, 300(1-3), 167-177.

Zhu, Y.G., Chen, S.B. ve Yang, J.C. (2004). Effects of soil amendments on lead uptake by two vegetable crops from a lead-contaminated soil from Anhui, China.Environment International, 30(3), 351356. 